Article

\title{
Sulfur Tolerant Magnesium Nickel Silicate Catalyst for Reforming of Biomass Gasification Products to Syngas
}

\author{
Richard Q. Long *, Scott M. Monfort, Gene B. Arkenberg, Paul H. Matter and Scott L. Swartz \\ NexTech Materials, Ltd., 404 Enterprise Drive, Lewis Center, OH 43035, USA; \\ E-Mails: s.monfort@nextechmaterials.com (S.M.M.); g.arkenberg@ nextechmaterials.com (G.B.A.); \\ phm@phmatter.com (P.H.M.); s.swartz@nextechmaterials.com (S.L.S.)
}

* Author to whom correspondence should be addressed; E-Mail: r.long@ nextechmaterials.com; Tel.: +1-614-842-6606; Fax: +1-614-842-6607.

Received: 17 January 2012; in revised form: 15 February 2012 / Accepted: 26 March 2012 / Published: 17 April 2012

\begin{abstract}
Magnesium nickel silicate (MNS) has been investigated as a catalyst to convert tars and light hydrocarbons to syngas $\left(\mathrm{CO}\right.$ and $\left.\mathrm{H}_{2}\right)$ by steam reforming and $\mathrm{CO}_{2}$ reforming in the presence of $\mathrm{H}_{2} \mathrm{~S}$ for biomass gasification process at NexTech Materials. It was observed that complete $\mathrm{CH}_{4}$ conversion could be achieved on MNS catalyst granules at $800-900{ }^{\circ} \mathrm{C}$ and a space velocity of $24,000 \mathrm{~mL} / \mathrm{g} / \mathrm{h}$ in a simulated biomass gasification stream. Addition of 10-20 ppm $\mathrm{H}_{2} \mathrm{~S}$ to the feed had no apparent impact on $\mathrm{CH}_{4}$ conversion. The MNS-washcoated monolith also showed high activities in converting methane, light hydrocarbons and tar to syngas. A $1200 \mathrm{~h}$ test without deactivation was achieved on the MNS washcoated monolith in the presence of $\mathrm{H}_{2} \mathrm{~S}$ and/or $\mathrm{NH}_{3}$, two common impurities in gasified biomass. The results indicate that the MNS material is a promising catalyst for removal of tar and light hydrocarbons from biomass gasified gases, enabling efficient use of biomass to produce power, liquid fuels and valuable chemicals.
\end{abstract}

Keywords: biomass gasification; tar reforming; sulfur; ammonia; magnesium nickel silicate; Ni catalyst; syngas

\section{Introduction}

As renewable energy, biomass conversion has gained more interest in recent years because of concerns related to global warming, gradual decreases in the known reserves of fossil fuels and 
increases in fossil fuel consumption. Gasification is an attractive route to convert biomass to syngas $\left(\mathrm{CO}+\mathrm{H}_{2}\right)$, which can be used in internal/external combustion engines, gas turbines and fuel cells for power generation, or further converted into hydrogen and liquid fuels such as methanol, dimethyl ether, ethanol, gasoline and diesel [1,2]. For biomass gasification, efficient cleaning and conditioning of the derived syngas is a significant barrier to commercializing this technology. Raw syngas contains impurities, such as sulfur, ammonia, tars, light hydrocarbons and methane. The methane and light hydrocarbons comprise un-used biomass carbon and hydrogen, which decrease the energy utilization efficiency. The tars mainly consist of polycyclic aromatic compounds with high boiling points, which will condense in the downstream process equipment. Therefore, these contaminants (e.g., tars) need to be removed from the gasification product gases.

Currently, two approaches are widely used for cleaning tars from biomass gasification product gases: liquid scrubbing and catalytic reforming. Liquid scrubbing removes tar in a condensed form. This approach requires the gasification products to be cooled to low temperatures, resulting in a loss of thermal efficiency. It also creates a liquid waste which needs to be further treated for disposal. In comparison, catalytic reforming of tar to syngas at high temperatures is a promising approach from an economic standpoint as it can utilize the sensible heat in the syngas, decrease the capital cost with simpler cooling systems, and enhance overall energy efficiency. It also converts the tar, methane and light hydrocarbons to syngas, increasing the fuel value.

Many catalysts have been reported to be active for tar reforming in the literature [3-35]. The types of catalysts depend on whether the catalysts are located within the gasifier, or in a secondary bed after the gasifier exit. For the former approach, particulate catalysts such as dolomite (a calcium carbonate based mineral) have been used in fluidized bed gasifiers [3-7]. Issues encountered include attrition of dolomite into smaller particles (which cannot be retained in the fluidized bed) and deactivation of the dolomite via carbon deposition. More recently, olivine-based minerals (modified with nickel) have been utilized for the same purpose [8-15], with benefits being the higher attrition resistance of olivine and its relatively high catalytic activity for tar reforming. A challenge in this case is that the chemical composition (and thus catalytic performance) of olivine mineral varies widely depending on location of the mine. This issue can be addressed by modifying the olivine composition in a separate step, but this would add cost and could potentially compromise the attrition resistance property of the olivine.

Alternatively, synthetic catalysts, especially $\mathrm{Ni}, \mathrm{Fe}$ and $\mathrm{Co}$, have been widely investigated for tar reforming due to the higher activity than the minerals [13,16,17,19,20,23,25-37]. It is known that Ni-based catalysts have been commercialized for steam methane reforming to produce $\mathrm{CO}$ and $\mathrm{H}_{2}$. These catalysts were also found to be very active for the tar reforming. For instance, Caballero et al. investigated several commercial $\mathrm{Ni}$ catalysts from ICI, UCI, BASF and Haldor-Topsoe for tar reforming and found that nearly $100 \%$ tar conversion could be achieved at $840{ }^{\circ} \mathrm{C}$ and $0.2-0.3 \mathrm{~s}$ residence time [27,28]. Other commercial $\mathrm{Ni}$-based catalysts were also tested for biomass tar reforming [29]. For Ni-based catalysts, it is likely that the use of support plays an important role in tar conversion. In many cases, $\mathrm{Al}_{2} \mathrm{O}_{3}$ is used as the main support. Addition of $\mathrm{MgO}$ to $\mathrm{Al}_{2} \mathrm{O}_{3}$ is found to enhance catalyst activity and stability. On a series of supported $\mathrm{Ni}$ catalysts, such as $\mathrm{Ni} / \mathrm{MgO}$, $\mathrm{Ni} / \gamma-\mathrm{Al}_{2} \mathrm{O}_{3}, \mathrm{Ni} / \alpha-\mathrm{Al}_{2} \mathrm{O}_{3}, \mathrm{Ni} / \mathrm{SiO}_{2}$ and $\mathrm{Ni} / \mathrm{ZrO}_{2}$, the activity of $\mathrm{CO}_{2}$ reforming of toluene (a model tar compound) was found to depend on Ni particle size, which is related to the interaction between $\mathrm{Ni}$ and the support [23]. The best catalytic performance was obtained on the $\mathrm{Ni} / \mathrm{MgO}$ due to the strong 
interaction between $\mathrm{NiO}$ and $\mathrm{MgO}$ within the $\mathrm{NiO}-\mathrm{MgO}$ solid solution. Precious metals are also active for the tar reforming reaction. On a series of precious metal supported $\mathrm{CeO}_{2}-\mathrm{SiO}_{2}$ catalysts, Tomishige et al. reported that the activity decreased in a sequence of $\mathrm{Rh}>\mathrm{Pt}>\mathrm{Pd}(\approx \mathrm{Ni})>\mathrm{Ru}[21]$. However, precious metal catalysts are expensive, making them less practical for tar reforming applications.

Although transition metal and precious metal based catalysts are active in converting tar to syngas, most of the testing data in the literature were reported in the absence of sulfur [2,33]. It is known that sulfur exists in biomass gasification gases. Tolerance to $\mathrm{H}_{2} \mathrm{~S}$ is critical for tar reforming catalysts because sulfur is difficult to be removed at gasification temperatures. In this work, we have developed a magnesium nickel silicate (MNS) catalyst for reforming of biomass gasification products at NexTech Materials. This MNS catalyst is found to be tolerant to $\mathrm{H}_{2} \mathrm{~S}$ and immune to $\mathrm{NH}_{3}$. This MNS catalyst can convert tars and light hydrocarbons to syngas by steam reforming and $\mathrm{CO}_{2}$ reforming at high temperatures in the presence of sulfur, enabling efficient use of biomass to produce power, liquid fuels and valuable chemicals.

\section{Results and Discussion}

\subsection{Properties of MNS Catalyst}

The XRD profile of MNS catalyst is shown in Figure 1. Only orthorhombic magnesium silicate phase was detected in the catalyst. $\mathrm{NiO}$ was not observed as a separate phase, suggesting $\mathrm{NiO}$ was dissolved in the magnesium silicate phase and/or dispersed well on the magnesium silicate surface.

Figure 1. XRD profile of magnesium nickel silicate (MNS) catalyst.

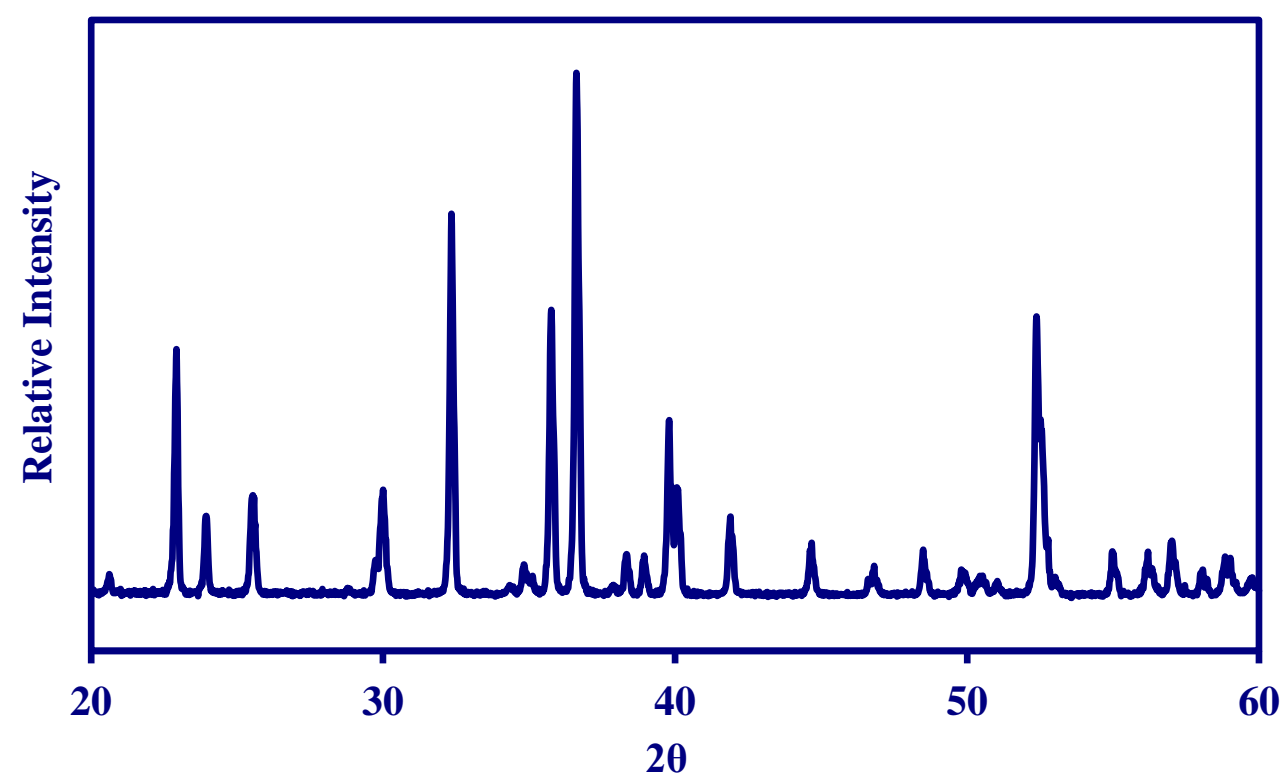

The catalyst reducibility was determined by $\mathrm{H}_{2}$-TPR. As shown in Figure 2, The MNS sample exhibited a low temperature reduction peak near $460{ }^{\circ} \mathrm{C}$ and a high temperature reduction peak near $740{ }^{\circ} \mathrm{C}$. Since $\mathrm{MgO}$ and $\mathrm{SiO}_{2}$ are difficult to be reduced below $800^{\circ} \mathrm{C}$, the two peaks can be attributed to the reduction of nickel oxides at two different sites. It is reported that, when $\mathrm{NiO}$ is deeply dissolved 
in $\mathrm{MgO}$ to form a solid solution [36] or reacts with $\mathrm{SiO}_{2}$ to generate nickel silicate compound [38], its reduction temperature is generally above $700-900{ }^{\circ} \mathrm{C}$. Hence, the higher temperature peak is probably related to the $\mathrm{NiO}$ deeply dissolved in the magnesium silicate phase, while the lower temperature peak is due to the $\mathrm{NiO}$ on the magnesium silicate surface with a weaker interaction.

Figure 2. $\mathrm{H}_{2}$-TPR profile of MNS catalyst.

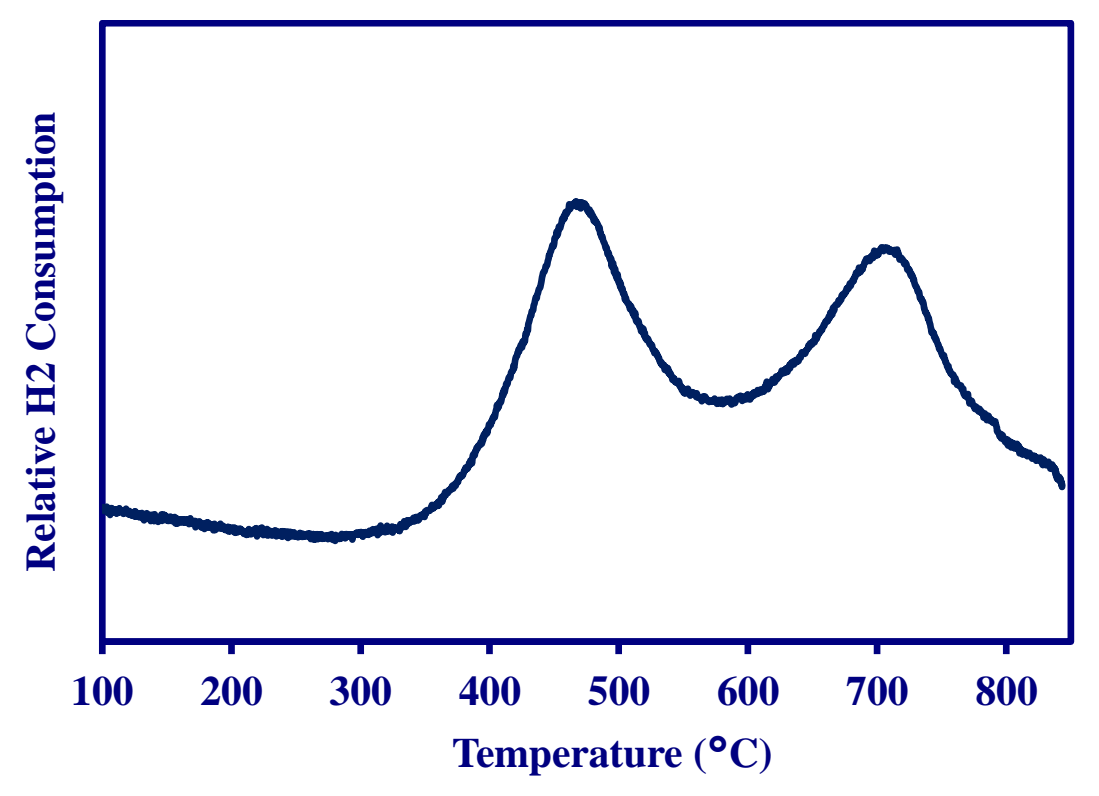

\subsection{Methane Reforming on Granulated Catalyst}

The MNS catalyst was tested for methane reforming with a simulated straw gasification stream of $3.7 \% \mathrm{H}_{2}, 8.4 \% \mathrm{CO}, 13.8 \% \mathrm{CO}_{2}, 7.8 \% \mathrm{CH}_{4}, 43.3 \% \mathrm{~N}_{2}$ and $23.0 \% \mathrm{H}_{2} \mathrm{O}$ (mole percent basis) [39]. As shown in Figure 3, the MNS exhibited nearly $100 \%$ initial $\mathrm{CH}_{4}$ conversion at $800{ }^{\circ} \mathrm{C}$ and a GHSV of $24,000 \mathrm{~mL} / \mathrm{g} / \mathrm{h}$, indicating this catalyst is highly active in steam reforming and dry reforming of methane to syngas under the testing conditions. $\mathrm{CO}$ selectivity was approximately $38 \%$ and $\mathrm{H}_{2} / \mathrm{CO}$ ratio was $5.2 . \mathrm{H}_{2}$ concentration in the product was $65 \%$. At $340 \mathrm{~h}$, the reaction temperature was increased to $900{ }^{\circ} \mathrm{C}$. $\mathrm{CO}$ selectivity was increased slightly to $42 \%$, while $\mathrm{CH}_{4}$ conversion remained at $100 \%$. $\mathrm{H}_{2} / \mathrm{CO}$ ratio was decreased to 4.4 correspondingly. The increase in $\mathrm{CO}$ selectivity with temperature is because reverse water gas shift reaction is more favorable at higher temperature. No change in methane reforming activity was observed during the initial $400 \mathrm{~h}$ testing.

At $400 \mathrm{~h}, 10 \mathrm{ppm} \mathrm{H}_{2} \mathrm{~S}$ was added to the feed at $900{ }^{\circ} \mathrm{C}$. The catalytic performance was unchanged for another approximately $200 \mathrm{~h}$ on stream (Figure 4). At $600 \mathrm{~h}$, the $\mathrm{H}_{2} \mathrm{~S}$ concentration was increased to $20 \mathrm{ppm}$ while keeping the other conditions unchanged. A slight initial decrease in $\mathrm{CH}_{4}$ conversion and CO selectivity was observed, but no further change was seen in additional $200 \mathrm{~h}$ testing (Figure 4). $\mathrm{CH}_{4}$ conversion remained at $98 \%$, while $\mathrm{CO}$ selectivity remained at $40 \%$. The above data indicated that the MNS catalyst was stable for $800 \mathrm{~h}$ during the testing under the conditions with $\mathrm{H}_{2} \mathrm{~S}$ and without $\mathrm{H}_{2} \mathrm{~S}$. It is noted that there are some data gaps during the activity testing for baking out GC columns. 
Figure 3. Reforming of biomass gasification products on MNS catalyst under the conditions of $3.7 \% \mathrm{H}_{2}, 8.4 \% \mathrm{CO}, 13.8 \% \mathrm{CO}_{2}, 7.8 \% \mathrm{CH}_{4}, 43.3 \% \mathrm{~N}_{2}, 23.0 \% \mathrm{H}_{2} \mathrm{O}$, and $\mathrm{GHSV}=24,000 \mathrm{~mL} / \mathrm{g} / \mathrm{h}$.

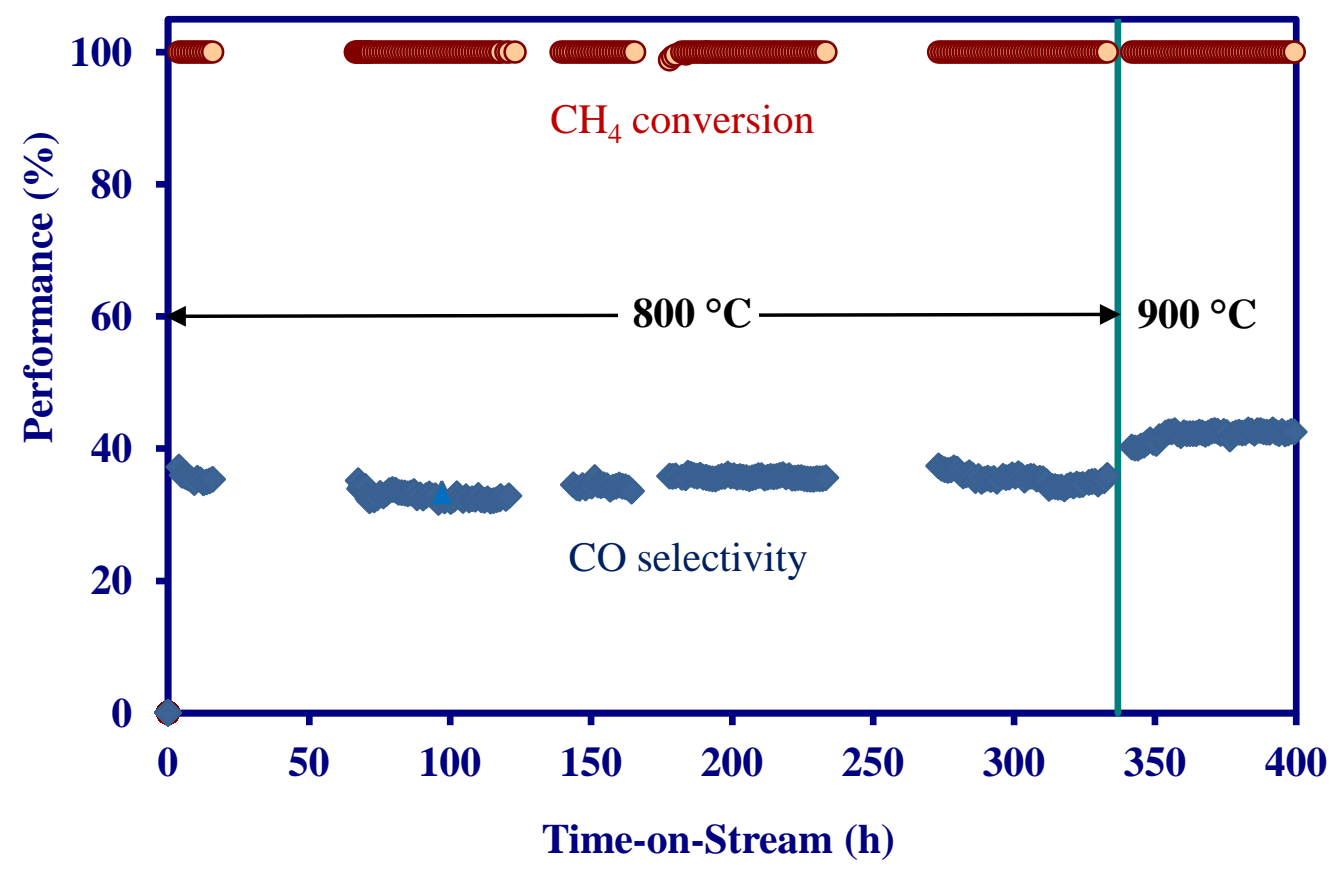

Figure 4. Effect of $\mathrm{H}_{2} \mathrm{~S}$ on catalytic performance of MNS catalyst under the conditions of $900{ }^{\circ} \mathrm{C}, 3.7 \% \mathrm{H}_{2}, 8.4 \% \mathrm{CO}, 13.8 \% \mathrm{CO}_{2}, 7.8 \% \mathrm{CH}_{4}, 43.3 \% \mathrm{~N}_{2}, 23.0 \% \mathrm{H}_{2} \mathrm{O}, 10$ and $20 \mathrm{ppm}$ $\mathrm{H}_{2} \mathrm{~S}$ (when used), and GHSV $=24,000 \mathrm{~mL} / \mathrm{g} / \mathrm{h}$.

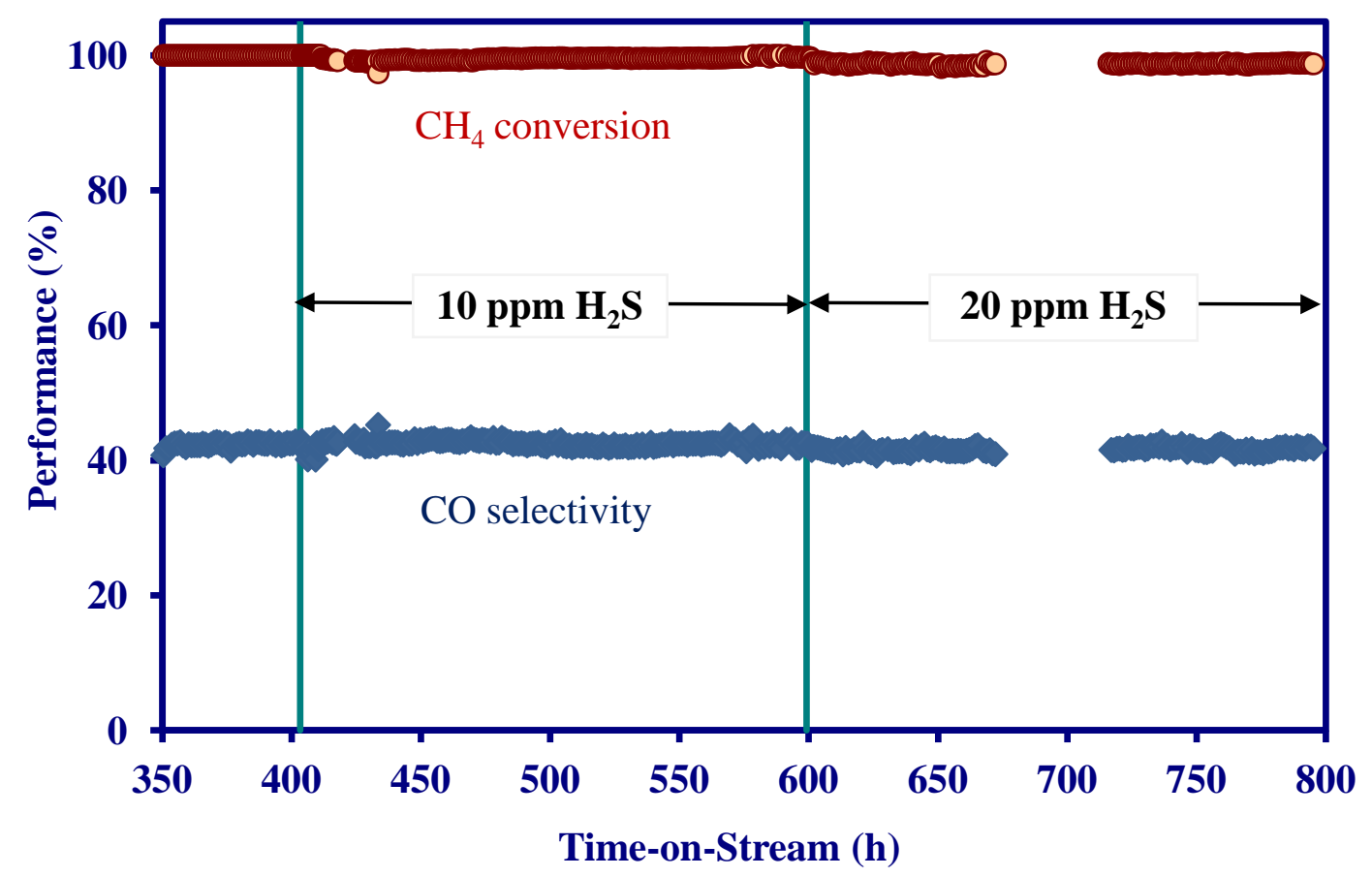




\subsection{Catalytic Performance of MNS Extruded Monolith}

Monolith catalysts, located at the tail end of gasifier, have been suggested for tar removal via steam reforming at elevated temperatures. Identified advantages of this include: (1) reduction of pressure drops associated with fixed/fluidized bed reactors; (2) reduction of carbon deposition (and clogging) of reactors that often occurs in fixed bed reactors; (3) potential for additional functionality (i.e., reforming of residual hydrocarbons into $\mathrm{H}_{2}$ and $\mathrm{CO}$ ); (4) the ability to use high activity catalysts that are not cost effective when used in fixed beds. The MNS catalyst was extruded to form a monolith with 400 CPSI, followed by calcination $1300{ }^{\circ} \mathrm{C}$ for one hour. Figure 5a shows a fresh MNS-extruded monolith with dark green color. Under the conditions of $850{ }^{\circ} \mathrm{C}$ and a space velocity of $10,000 \mathrm{~h}^{-1}$, less than $25 \%$ $\mathrm{CH}_{4}$ conversion was obtained on the extruded monolith in flowing $3.7 \% \mathrm{H}_{2}, 7.6 \% \mathrm{CH}_{4}, 8.5 \% \mathrm{CO}$, $13.9 \% \mathrm{CO}_{2}, 23.4 \% \mathrm{H}_{2} \mathrm{O}$, and $42.9 \% \mathrm{~N}_{2}$. A BET surface area analysis confirmed that the cause for the low performance was the low surface area of the monolith material. After calcination at $1300{ }^{\circ} \mathrm{C}$ during monolith manufacturing, the surface area of the MNS was decreased to only $0.13 \mathrm{~m}^{2} / \mathrm{g}$ from the previous $4.0 \mathrm{~m}^{2} / \mathrm{g}$.

Figure 5. Pictures of (a) MNS extruded monolith and (b) MNS washcoated cordierite monolith.

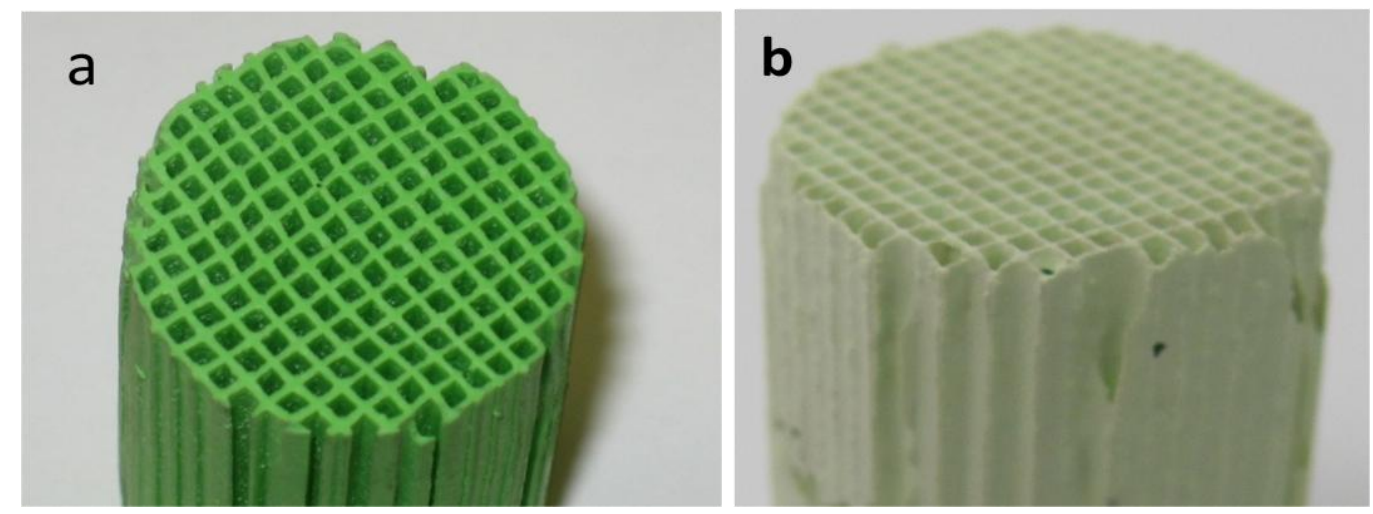

To increase the monolith activity, fine-scale MNS powder were washcoated onto the extruded monolith. It was observed that, under the same reaction conditions, approximately $90-100 \% \mathrm{CH}_{4}$ conversion was achieved at $900{ }^{\circ} \mathrm{C}$, while $\mathrm{CO}$ selectivity was 60-65\% (Figure 6). $\mathrm{H}_{2}$ concentration in the product was $55 \%$ and $\mathrm{H}_{2} / \mathrm{CO}$ ratio was approximately 1.8 . As compared to the granule catalyst (Figure 4), the higher $\mathrm{CO}$ selectivity on the monolith catalyst might be due to more $\mathrm{CO}_{2}$ reforming at the lower space velocity. At $70 \mathrm{~h}$, the reaction temperature was decreased to $850{ }^{\circ} \mathrm{C}$. An initial decrease in $\mathrm{CH}_{4}$ conversion was observed, but it recovered to nearly $100 \%$ slowly. This observation suggests an activation process for the catalyst during the testing. When more active sites are available on the surface with time, the catalyst exhibits higher reforming activity. CO selectivity also decreased to approximately $58 \%$. The monolith catalyst achieved $90-100 \%$ methane conversion in 600 -h testing. This result demonstrated that washcoating of MNS catalyst powders on the extruded monolith increased its reforming activity significantly. 
Figure 6. Reforming of biomass gasification products on a MNS-washcoated on catalyst-extruded monolith under the conditions of $3.7 \% \mathrm{H}_{2}, 7.6 \% \mathrm{CH}_{4}, 8.5 \% \mathrm{CO}$, $13.9 \% \mathrm{CO}_{2}, 23.4 \% \mathrm{H}_{2} \mathrm{O}$, and $42.9 \% \mathrm{~N}_{2}$, and $\mathrm{GHSV}=10,000 \mathrm{~h}^{-1}$.

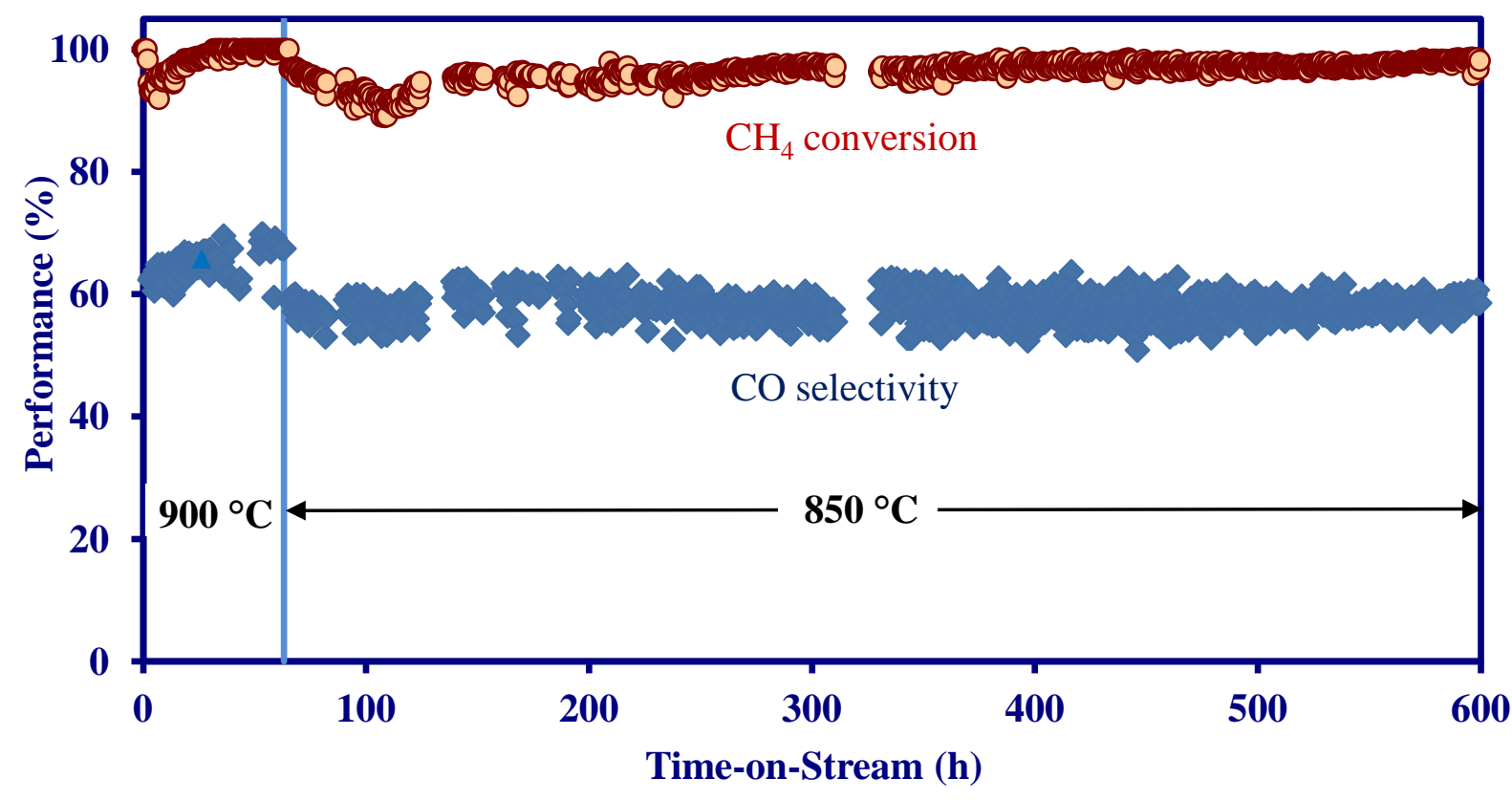

\subsection{Catalytic Performance of MNS Washcoated Cordierite Monolith}

The MNS catalyst was also washcoated on a cordierite monolith (400 CPSI). The color of the MNS-washcoated monolith is light green (Figure 5b), similar to the catalyst color. The monolith was tested for reforming of oak wood gasification products [40] under the conditions of $900{ }^{\circ} \mathrm{C}, 14.4 \% \mathrm{H}_{2}$, $10.4 \% \mathrm{CO}, 9.8 \% \mathrm{CO}_{2}, 5.8 \% \mathrm{CH}_{4}, 13.2 \% \mathrm{~N}_{2}, 44.6 \% \mathrm{H}_{2} \mathrm{O}, 1.6 \% \mathrm{C}_{2} \mathrm{H}_{6}$ and $\mathrm{C}_{2} \mathrm{H}_{4}, 0.2 \% \mathrm{C}_{3} \mathrm{H}_{8}$ and $\mathrm{C}_{3} \mathrm{H}_{6}$, $30 \mathrm{ppm}$ naphthalene (when used), $22 \mathrm{ppm} \mathrm{H}_{2} \mathrm{~S}$ and GHSV $=10,000 \mathrm{~h}^{-1} \cdot \mathrm{H}_{2} \mathrm{~S}$, naphthalene, $\mathrm{C}_{2}$ and $\mathrm{C}_{3}$ hydrocarbons were added to the feed for this testing.

As shown in Figure 7, $\mathrm{C}_{2+}$ hydrocarbon conversion reached $87 \%$ on the MNS-washcoated cordierite monolith in the presence of $\mathrm{H}_{2} \mathrm{~S}$, while $\mathrm{CH}_{4}$ conversion was approximately $20 \%$. CO selectivity was $55 \% . \mathrm{H}_{2}$ concentration in the product was $35 \%$ and $\mathrm{H}_{2} / \mathrm{CO}$ ratio was approximately 1.8 . For the $\mathrm{C}_{2+}$ hydrocarbons, propane and propylene were not detected in the product, indicating complete conversions. Approximately $85 \%$ of ethane and ethylene conversion was obtained. The above data indicate that, for reforming of the light hydrocarbons, the activity decreased in a sequence of $\mathrm{C}_{3}$ hydrocarbons $(100 \%)>\mathrm{C}_{2}$ hydrocarbons $(85 \%)>$ methane $(20 \%)$ on the MNS-washcoated monolith in the presence of sulfur. This is likely due to the difference in $\mathrm{C}-\mathrm{H}$ bond dissociation energy in these hydrocarbons. For example, the $\mathrm{C}-\mathrm{H}$ bond energy in the hydrocarbons decreases in a sequence of $\mathrm{CH}_{4}(103 \mathrm{kcal} / \mathrm{mol})>\mathrm{C}_{2} \mathrm{H}_{6}(98 \mathrm{kcal} / \mathrm{mol})>\mathrm{C}_{3} \mathrm{H}_{8}(95 \mathrm{kcal} / \mathrm{mol})$, which is in reverse order of their reforming activity. In a separate test under the same conditions but without $\mathrm{H}_{2} \mathrm{~S}$, almost complete $\mathrm{CH}_{4}$ and $\mathrm{C}_{2+}$ hydrocarbon conversions were achieved (not shown), suggesting the presence of $\mathrm{H}_{2} \mathrm{~S}$ decreased monolith catalyst reforming activity.

At $165 \mathrm{~h}, 30 \mathrm{ppm}$ naphthalene (a model tar compound) was added to the feed with sulfur, the catalytic performance did not change. Naphthalene was not detected in the exhaust by a mass 
spectrometer, suggesting that the catalyst was effective in breaking down the double ringed structure and converting it into syngas. The MNS catalyst was tested for $500 \mathrm{~h}$ in the presence of $\mathrm{H}_{2} \mathrm{~S}$ and no deactivation was seen (Figure 7). This indicates that the catalyst was stable in the presence of $\mathrm{H}_{2} \mathrm{~S}$.

Figure 7. Reforming of biomass gasification products on a MNS-washcoated cordierite monolith in the presence of $\mathrm{H}_{2} \mathrm{~S}$ under the conditions of $900{ }^{\circ} \mathrm{C}$, GHSV $=10,000 \mathrm{~h}^{-1}$, $14.4 \% \mathrm{H}_{2}, 10.4 \% \mathrm{CO}, 9.8 \% \mathrm{CO}_{2}, 5.8 \% \mathrm{CH}_{4}, 13.2 \% \mathrm{~N}_{2}, 44.6 \% \mathrm{H}_{2} \mathrm{O}, 1.6 \% \mathrm{C}_{2} \mathrm{H}_{6}$ and $\mathrm{C}_{2} \mathrm{H}_{4}$, $0.2 \% \mathrm{C}_{3} \mathrm{H}_{8}$ and $\mathrm{C}_{3} \mathrm{H}_{6}, 30 \mathrm{ppm}$ naphthalene (when used) and $22 \mathrm{ppm} \mathrm{H}_{2} \mathrm{~S}$.

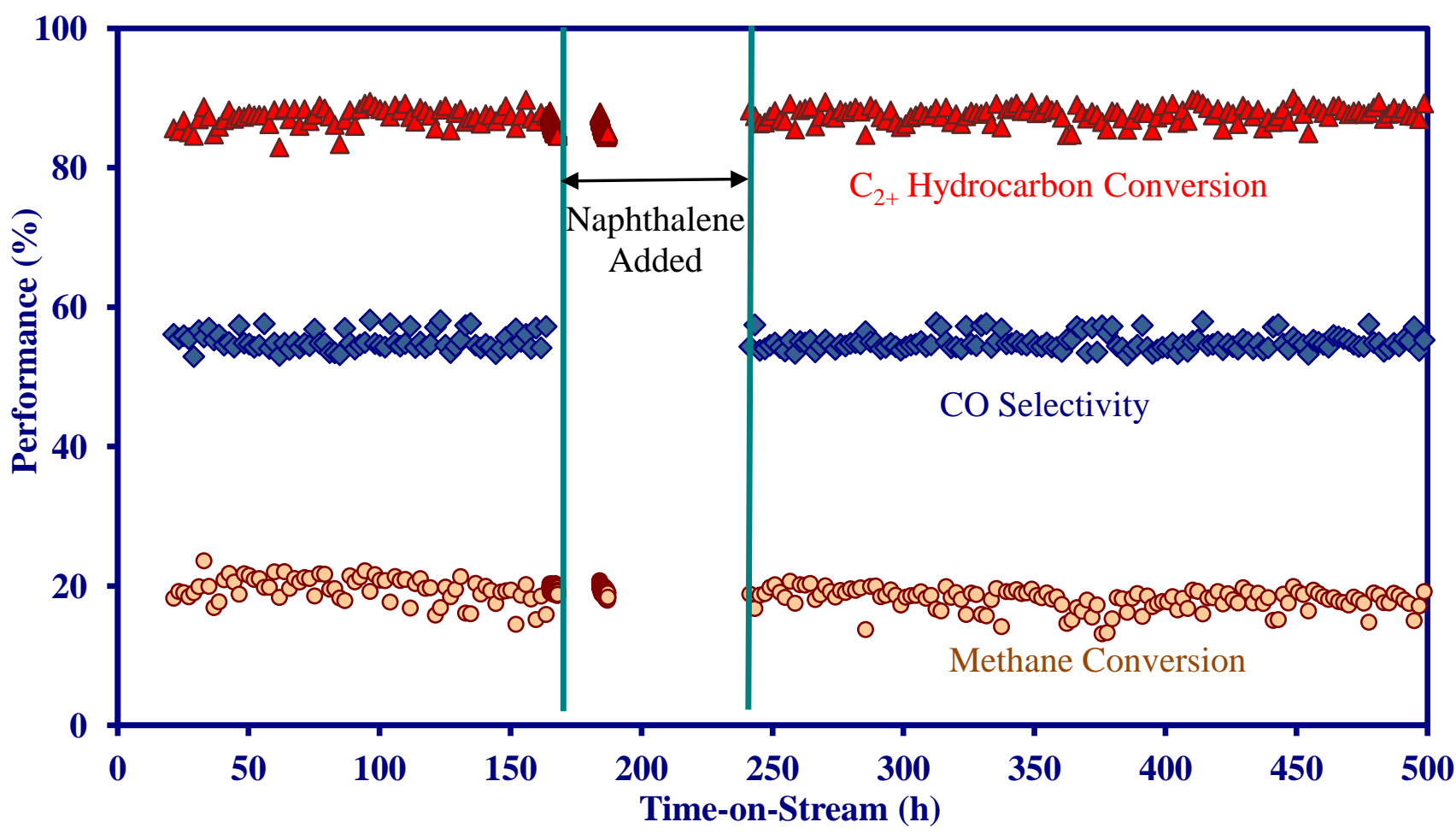

Beyond the initial $500 \mathrm{~h}$ testing, additional conditions were investigated to determine the monolith's performance at different temperatures. The feed flow rate was adjusted to obtain complete $\mathrm{C}_{2+}$ hydrocarbon conversion at $900{ }^{\circ} \mathrm{C}, 875{ }^{\circ} \mathrm{C}$, and $850{ }^{\circ} \mathrm{C}$ in the presence of $\mathrm{H}_{2} \mathrm{~S}$. A summary of this testing is provided in Table 1 . At $900{ }^{\circ} \mathrm{C}$, complete $\mathrm{C}_{2+}$ hydrocarbon conversion could be obtained at a gas space velocity of $5000 \mathrm{~h}^{-1}$. A decrease in reaction temperature decreased catalyst activity and required progressively lower gas flow rate to achieve near complete $\mathrm{C}_{2+}$ hydrocarbon conversion. At $875{ }^{\circ} \mathrm{C}$, complete $\mathrm{C}_{2+}$ hydrocarbon conversion was obtained at a gas space velocity of $3000 \mathrm{~h}^{-1}$. When the temperature was decreased to $850{ }^{\circ} \mathrm{C}$, nearly complete $\mathrm{C}_{2+}$ hydrocarbon conversion could be obtained at $1800 \mathrm{~h}^{-1} \cdot \mathrm{CH}_{4}$ conversion also changed with the reaction temperature and gas flow rate (Table 1). 
Table 1. Reforming of biomass gasification products on a MNS-washcoated cordierite monolith in the presence of $\mathrm{H}_{2} \mathrm{~S}$.

\begin{tabular}{cccc}
\hline $\begin{array}{c}\text { Monolith } \\
\text { Temperature }\left({ }^{\circ} \mathbf{C}\right)\end{array}$ & $\begin{array}{c}\text { Space Velocity } \\
\left(\mathbf{h}^{\mathbf{- 1}}\right)\end{array}$ & $\begin{array}{c}\mathbf{C}_{\mathbf{2}} \text { Conversion } \\
\mathbf{( \% )}\end{array}$ & $\begin{array}{c}\text { Methane } \\
\text { Conversion (\%) }\end{array}$ \\
\hline 900 & 5000 & 100 & 37 \\
875 & 3000 & 100 & 27 \\
850 & 1800 & 99 & 20 \\
\hline
\end{tabular}

Feed gas composition: $14.4 \% \mathrm{H}_{2}, 10.4 \% \mathrm{CO}, 9.8 \% \mathrm{CO}_{2}, 5.8 \% \mathrm{CH}_{4}, 13.2 \% \mathrm{~N}_{2}, 44.6 \% \mathrm{H}_{2} \mathrm{O}$, $1.6 \% \mathrm{C}_{2} \mathrm{H}_{6}$ and $\mathrm{C}_{2} \mathrm{H}_{4}, 0.2 \% \mathrm{C}_{3} \mathrm{H}_{8}$ and $\mathrm{C}_{3} \mathrm{H}_{6}$, and $22 \mathrm{ppm}_{2} \mathrm{~S}$.

After concluding the study summarized by Table 1, the reaction conditions were returned to the initial conditions: $900{ }^{\circ} \mathrm{C}$ and GHSV $=10,000 \mathrm{~h}^{-1}$. As shown in Figure $8, \mathrm{C}_{2+}$ hydrocarbon conversion was maintained at approximately $87 \%$, while $\mathrm{CH}_{4}$ conversion decreased slightly to $18 \%$. After the MNS-washcoated monolith was tested for $1000 \mathrm{~h}, 1000 \mathrm{ppm} \mathrm{NH}_{3}$ was added to the feed while the other conditions were kept the same. It can be seen that the addition of $\mathrm{NH}_{3}$ did not impact the performance of the catalyst. All major exhaust compositions were shown to be consistent before and after the $\mathrm{NH}_{3}$ addition. This suggests that the catalyst was stable in the presence of both $\mathrm{H}_{2} \mathrm{~S}$ and $\mathrm{NH}_{3}$, two major impurities in biomass gasification products.

Figure 8. Reforming of biomass gasification products on MNS-washcoated cordierite monolith in the presence of $\mathrm{NH}_{3}$ and $\mathrm{H}_{2} \mathrm{~S}$ under the conditions of $900{ }^{\circ} \mathrm{C}$, GHSV $=10,000 \mathrm{~h}^{-1}, 14.4 \% \mathrm{H}_{2}, 10.4 \% \mathrm{CO}, 9.8 \% \quad \mathrm{CO}_{2}, 5.8 \% \quad \mathrm{CH}_{4}, \quad 13.2 \% \quad \mathrm{~N}_{2}$, $44.6 \% \mathrm{H}_{2} \mathrm{O}, 1.6 \% \mathrm{C}_{2} \mathrm{H}_{6}$ and $\mathrm{C}_{2} \mathrm{H}_{4}, 0.2 \% \mathrm{C}_{3} \mathrm{H}_{8}$ and $\mathrm{C}_{3} \mathrm{H}_{6}, 1000 \mathrm{ppm} \mathrm{NH}_{3}$ (when used) and $22 \mathrm{ppm} \mathrm{H}_{2} \mathrm{~S}$.

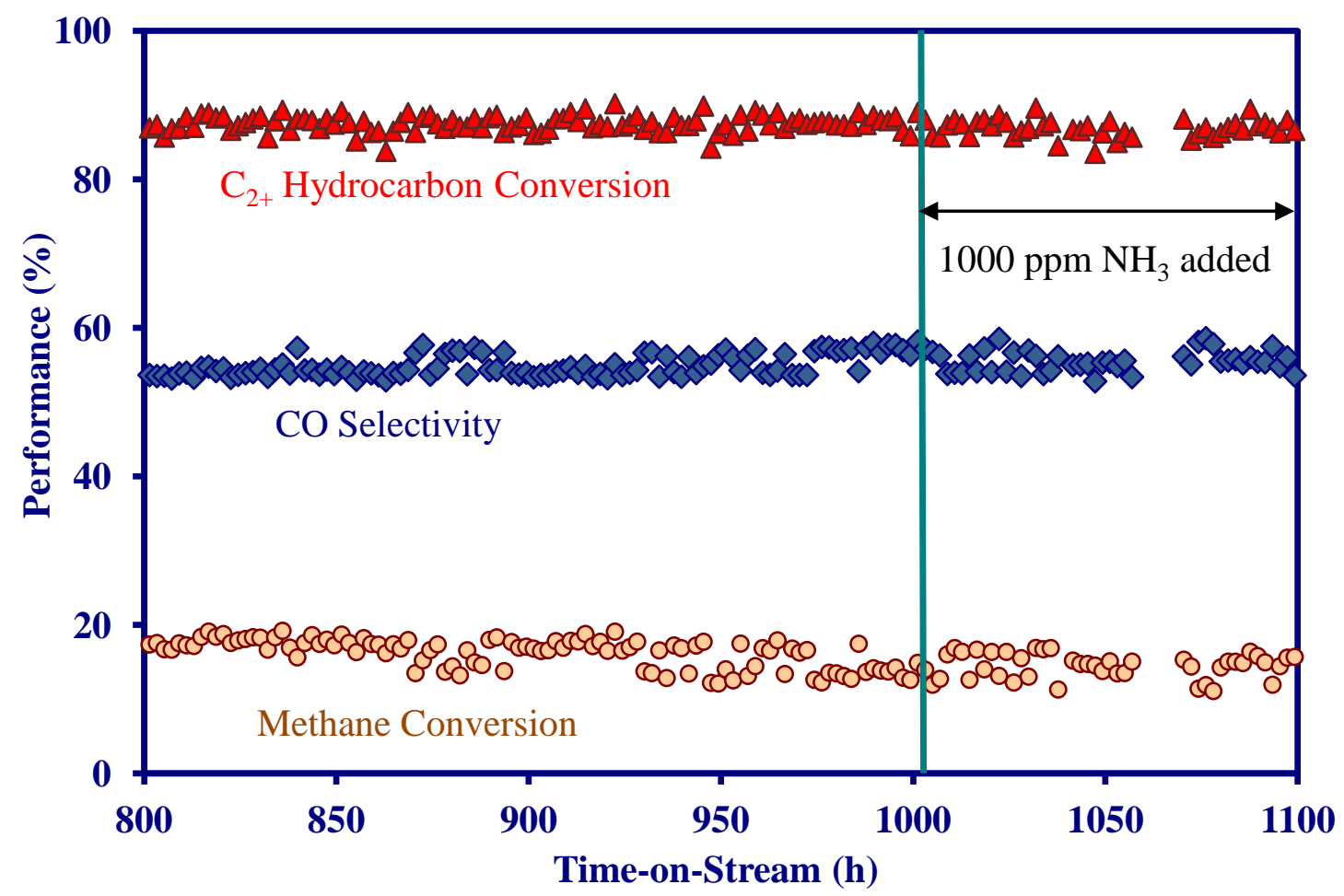


At $1145 \mathrm{~h}, \mathrm{H}_{2} \mathrm{~S}$ was removed from the feed stream while maintaining $\mathrm{NH}_{3}$ concentration at $1000 \mathrm{ppm}$. $\mathrm{C}_{2+}$ hydrocarbon and $\mathrm{CH}_{4}$ conversions were increased to about $100 \%$ and above $95 \%$, respectively (Figure 9). $\mathrm{CO}$ selectivity did not change significantly. $\mathrm{H}_{2}$ concentration in the product was increased to $53 \%$ and $\mathrm{H}_{2} / \mathrm{CO}$ ratio was approximately 2.7 . The catalyst activity was almost identical to that in the absence of sulfur and ammonia. This further supports the conclusion that $\mathrm{NH}_{3}$ did not impact the reforming activity of this catalyst. Additionally, the quick increase in $\mathrm{C}_{2+}$ hydrocarbon and methane conversions also suggests that $\mathrm{H}_{2} \mathrm{~S}$ has a reversible degradation effect on the catalyst. Upon $\mathrm{H}_{2} \mathrm{~S}$ removal, the catalytic performance was recovered quickly.

Figure 9. Reforming of biomass gasification products on MNS-washcoated cordierite monolith in the presence of $\mathrm{NH}_{3}$ and $\mathrm{H}_{2} \mathrm{~S}$ under the conditions of $900{ }^{\circ} \mathrm{C}$, GHSV $=10,000 \mathrm{~h}^{-1}, 14.4 \% \mathrm{H}_{2}, 10.4 \% \mathrm{CO}, 9.8 \% \mathrm{CO}_{2}, 5.8 \% \mathrm{CH}_{4}, 13.2 \% \mathrm{~N}_{2}, 44.6 \% \mathrm{H}_{2} \mathrm{O}$, $1.6 \% \quad \mathrm{C}_{2} \mathrm{H}_{6}$ and $\mathrm{C}_{2} \mathrm{H}_{4}, \quad 0.2 \% \quad \mathrm{C}_{3} \mathrm{H}_{8}$ and $\mathrm{C}_{3} \mathrm{H}_{6}, \quad 1000 \quad \mathrm{ppm} \quad \mathrm{NH}_{3}$ and $22 \mathrm{ppm}$ $\mathrm{H}_{2} \mathrm{~S}$ (when used).

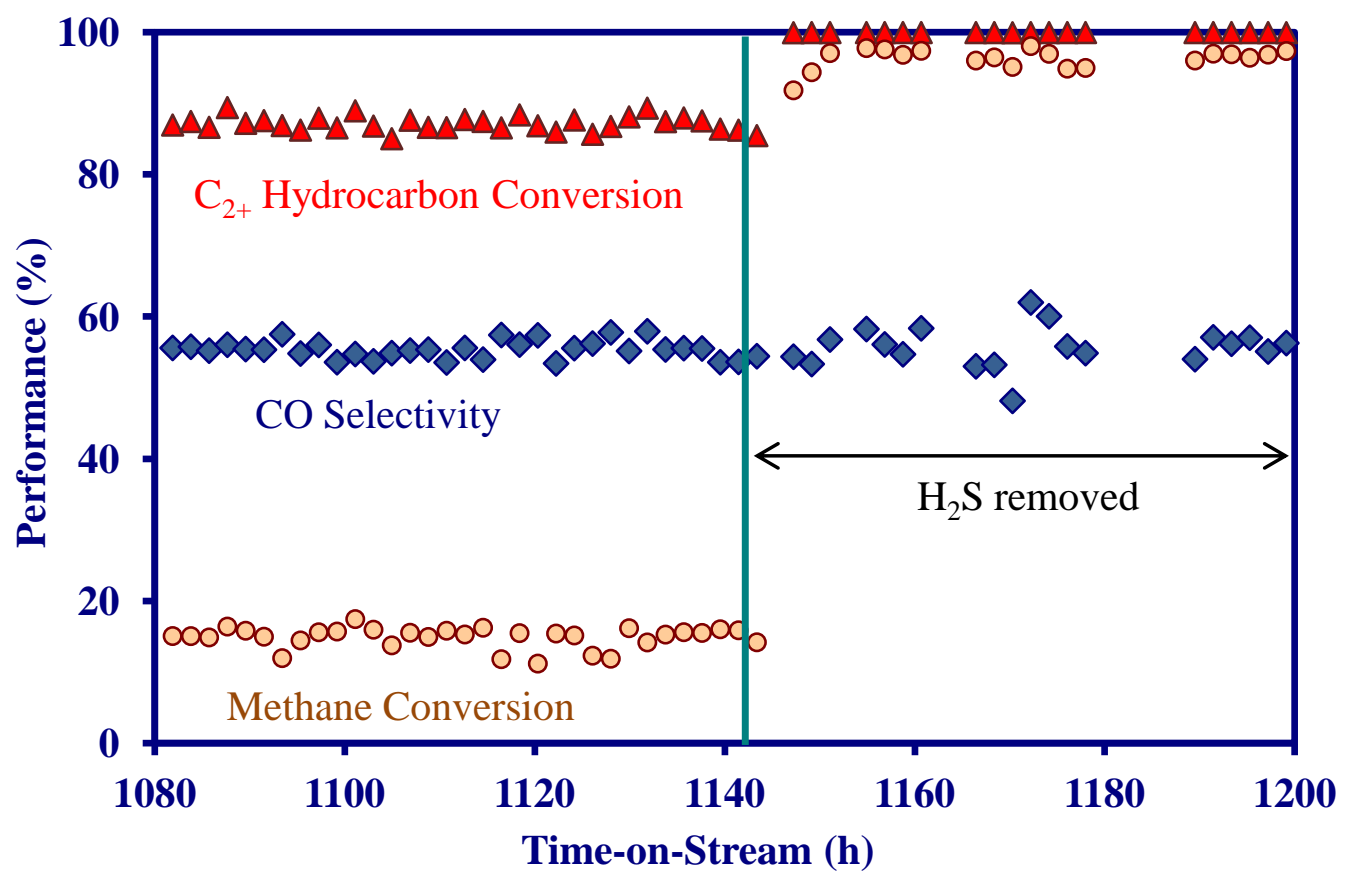

After the ammonia tolerance testing, the feed gas was changed back to the original conditions with 22 ppm $\mathrm{H}_{2} \mathrm{~S}$ at 1200 h. $87 \% \mathrm{C}_{2+}$ hydrocarbon conversion and $18 \% \mathrm{CH}_{4}$ conversion were still obtained. The testing data have proven that the MNS catalyst is robust for reforming of biomass gasification products. It is stable in the presence of $\mathrm{H}_{2} \mathrm{~S}$ and $\mathrm{NH}_{3}$, which are impurities in biomass gasification gases.

The above testing data have indicated that the magnesium nickel silicate is highly active in reforming of tar and light hydrocarbons to syngas for biomass gasification process in the presence of sulfur and ammonia. In the catalyst, $\mathrm{NiO}$ phase was not detected by XRD, indicating it is highly dispersed on the magnesium silicate surface and/or dissolved in the phase, which is considered to be beneficial to the reforming activity in the literature [27-35]. Consequently, the MNS catalyst granules achieved complete methane conversion at $900{ }^{\circ} \mathrm{C}$ and a space velocity of $24,000 \mathrm{~mL} / \mathrm{g} / \mathrm{h}$. The addition of 10-20 ppm $\mathrm{H}_{2} \mathrm{~S}$ to the feed had no apparent impact on the performance (both methane conversion and $\mathrm{CO}$ selectivity) (Figure 4). In comparison, $\mathrm{CH}_{4}$ and $\mathrm{C}_{2+}$ hydrocarbon conversions were decreased 
by $\mathrm{H}_{2} \mathrm{~S}$ on the MNS washcoated monoliths. It is likely that the total amount of active sites on the granules is more than enough for complete hydrocarbon reforming under the testing conditions. When the catalyst is partially poisoned by $\mathrm{H}_{2} \mathrm{~S}$, the amount of the active sites is still enough to convert all of the hydrocarbons. Hence the addition of $\mathrm{H}_{2} \mathrm{~S}$ did not have "apparent" impact on methane conversion on the granule catalyst. This might not be the case for the MNS washcoated catalyst, resulting in a decrease in activity. Moreover, this MNS catalyst has shown excellent stability over hundreds of hours of testing. Deactivation was not observed in $800 \mathrm{~h}$ of testing of the granulated catalyst (Figures 3 and 4) and not seen in $1200 \mathrm{~h}$ of testing of the monolithic catalyst (Figures 7-9) in the absence/presence of $\mathrm{H}_{2} \mathrm{~S}$ and $\mathrm{NH}_{3}$. Complete light hydrocarbon conversion was achieved on the MNS-washcoated monolith in the presence of $\mathrm{H}_{2} \mathrm{~S}$ at $900{ }^{\circ} \mathrm{C}$ and $\mathrm{GHSV}=5000 \mathrm{~h}^{-1}$ (Table 1). In the literature, some Ni-based catalysts are reported to deactivate in steam reforming of tar due to coking and sulfur poisoning. On $\mathrm{Ni} / \mathrm{Al}_{2} \mathrm{O}_{3}$ [17] and $\mathrm{Ni} / \mathrm{CeO}_{2}-\mathrm{ZrO}_{2}$ [19], carbon deposition is reported to result in loss of tar reforming activity. Typical characteristics of deactivation by coking are that the catalyst activity drops and pressure drop increases continuously with time until the catalyst surface is fully covered by carbon deposition or the reactor channel is blocked by the coke. In this work, our MNS catalyst was continuously tested without deactivation and without discernible increases in pressure drop for 800-1200 h, suggesting that the catalyst was not coked during the testing. In fact, coke was not detected on the used catalyst by SEM analysis. It is reported that $\mathrm{NiO}$ can dissolve in $\mathrm{MgO}$ and form solid $\mathrm{NiXMg1-XO}$ solution, resulting in excellent anti-coking property in reforming methane and other hydrocarbons [25]. It is likely that the $\mathrm{NiO}$ in the MNS catalyst is also dissolved in the magnesium silicate phase to form solid solution for the anti-coking purpose, as evidenced by no $\mathrm{NiO}$ phase detected in the XRD analysis (Figure 1).

For sulfur poisoning, it is known that $\mathrm{H}_{2} \mathrm{~S}$ in the reaction gas tends to react with $\mathrm{Ni}$ in the catalysts to form non-active surface Ni-S [41]. Consequently most of the Ni-based reforming catalysts are poisoned by sulfur, resulting in activity loss irreversibly. It is reported that doping a sulfur-resistant promoter $\mathrm{WO}_{3}$ onto $\mathrm{Ni} / \mathrm{MgO}-\mathrm{CaO}$ catalyst has enhanced the tolerance to sulfur because tungsten promotes sulfur dissociation via the reactions $\mathrm{NiS}_{\mathrm{X}}+\mathrm{W}=\mathrm{WS}_{\mathrm{X}}+\mathrm{Ni}$ and $\mathrm{WS}_{\mathrm{X}}+\mathrm{xH}_{2}=\mathrm{W}+\mathrm{xH}_{2} \mathrm{~S}$ [25]. On a nickel calcium aluminum catalyst $\left(\mathrm{Ni} / \mathrm{Ca}_{12} \mathrm{Al}_{14} \mathrm{O}_{33}\right)$, Li et al. also reports an initial sulfur resistance compared to the commercial $\mathrm{Ni} / \mathrm{Al}_{2} \mathrm{O}_{3}$ and $\mathrm{Ni} / \mathrm{CaO}-\mathrm{MgO}$ catalysts [32]. The catalyst can sustain sulfur poisoning without loss of tar reforming activity for approximately one hour under the testing conditions due to the presence of $\mathrm{O}_{2}{ }^{-}$and $\mathrm{O}_{2}{ }^{2-}$ adsorbed species on the surface. The "free oxygen" in the catalyst structure can be substituted preferably by sulfur and thus prolongs Ni lifetime. However, the adsorbed $\mathrm{S}$ atom is hardly re-substituted by $\mathrm{O}_{2}$, resulting in a permanent deactivation late. In this work, the MNS catalyst lost some activity in the presence of sulfur, suggesting the catalyst is partially poisoned by the sulfur. However, no further deactivation was observed over $1200 \mathrm{~h}$ of testing (Figures 7-9), indicating the catalyst is stable in the presence of sulfur. Further, the sulfur poisoning effect is reversible. After sulfur was removed from the feed gas, the catalyst activity was fully recovered quickly (Figure 9). This indicates that the sulfur adsorption on the MNS catalyst is relatively weak. It can be removed by steam and $\mathrm{H}_{2}$ under the testing conditions. Consequently, after the $\mathrm{H}_{2} \mathrm{~S}$ is removed from the feed, the reforming activity is restored. For the MNS catalyst, the reason for the tolerance to sulfur poisoning is not clear at present time. It might be related to the solid solution 
formation and interaction between the $\mathrm{NiO}$ and magnesium silicate, resulting in a weaker adsorption of sulfur on the Ni surface.

The addition of $1000 \mathrm{ppm} \mathrm{NH}_{3}$ did not impact the catalytic performance at $900{ }^{\circ} \mathrm{C}$ in the presence and absence of $\mathrm{H}_{2} \mathrm{~S}$ (Figure 8), indicating the MNS catalyst is immune to $\mathrm{NH}_{3}$. The resistance to $\mathrm{NH}_{3}$ poisoning is possibly due to the weak adsorption of ammonia and nitrogen atom on the MNS catalyst surface. In fact, Ni-supported materials have been investigated as catalysts for $\mathrm{NH}_{3}$ decomposition for biomass gasification process. Ni-based catalysts are reported to be active in decomposing $\mathrm{NH}_{3}$ to $\mathrm{N}_{2}$ and $\mathrm{H}_{2}$ at high temperatures $\left(>800{ }^{\circ} \mathrm{C}\right)$ and the ammonia conversion increases with $\mathrm{Ni}$ content in the catalysts [33]. As a result, the addition of $\mathrm{NH}_{3}$ to the feed does not impact the activity of the MNS catalyst. Overall, the present testing data suggests that this MNS material is a promising catalyst for reforming of tar and light hydrocarbons to $\mathrm{CO}$ and $\mathrm{H}_{2}$ for biomass gasification process in the presence of $\mathrm{H}_{2} \mathrm{~S}$ and $\mathrm{NH}_{3}$, enabling efficient use of biomass to produce power, liquid fuels and valuable chemicals.

\section{Experimental Section}

\subsection{Catalyst Preparation and Characterization}

Magnesium nickel silicate (MNS) catalyst was prepared by solid-state reaction. The as-prepared material had a BET surface area of $4 \mathrm{~m}^{2} / \mathrm{g}$. For catalyst activity testing, the powders were pressed, crushed and sieved to 35-60 mesh.

In addition, the MNS catalyst was extruded to form a 0.75 in (O.D.) $\times 1.5$ in (length) monolith with 400 cells per square inch (CPSI), followed by calcination $1300{ }^{\circ} \mathrm{C}$ for $1 \mathrm{~h}$. The formed monolith had strength of $82.5 \mathrm{MPa} / \mathrm{cm}$. The MNS powders were washcoated on the MNS-extruded monolith and a cordierite monolith (400 CPSI, 0.75 in (O.D.) $\times 1.5$ in (length), obtained from Applied Ceramics) by dip coating. The washcoated monoliths were calcined at $1000{ }^{\circ} \mathrm{C}$ for $4 \mathrm{~h}$. The catalyst loading in the monolith was $180 \mathrm{~g}$ per liter.

BET surface area was measured with a Micromeritics TriStar system. X-ray diffraction (XRD) analysis was performed with a Scintag XDS2000 instrument. Catalyst reducibility was analyzed by $\mathrm{H}_{2}$-TPR (temperature programmed reduction), using a Micromeritics AutoChem 2910 system. $50 \mathrm{mg}$ sample was heated to $850{ }^{\circ} \mathrm{C}$ at $10{ }^{\circ} \mathrm{C} / \mathrm{min}$ in $5 \% \mathrm{H}_{2} / \mathrm{Ar}$ at a flow rate of $50 \mathrm{SCCM}$. A thermal conductivity detector (TCD) was used to measure $\mathrm{H}_{2}$ consumption amount during heating.

\subsection{Catalyst Performance Testing}

Catalyst granules (35-60 mesh) were evaluated for reforming of methane to $\mathrm{CO}+\mathrm{H}_{2}$ in a simulated biomass gasification product stream. The feed gas had a composition of $3.7 \% \mathrm{H}_{2}, 8.4 \% \mathrm{CO}$, $13.8 \% \mathrm{CO}_{2}, 7.8 \% \mathrm{CH}_{4}, 43.3 \% \mathrm{~N}_{2}, 23.0 \% \mathrm{H}_{2} \mathrm{O}$ and $10-20 \mathrm{ppm}_{2} \mathrm{~S}$ (when used). $0.5 \mathrm{~g}$ catalyst was loaded in a 0.25 inch stainless steel reactor. The total gas flow rate was $200 \mathrm{~mL} / \mathrm{min}$ and the gas hourly space velocity was $24,000 \mathrm{~mL} / \mathrm{g} / \mathrm{h}$.

The MNS extruded monolith and washcoated monoliths were tested for reforming of methane, light hydrocarbons and tar (using naphthalene as a model compound) to syngas in a simulated biomass gasification product stream. The monoliths were loaded in one inch (OD) stainless steel reactors for the testing. A vaporizer produced steam from a liquid feed supplied by an Eldex 2HM pump. The 
vaporizer consisted of an initial section operated at $150{ }^{\circ} \mathrm{C}$ and second section held at $300{ }^{\circ} \mathrm{C}$. After exit of the second section, the steam was mixed with $\mathrm{CO}, \mathrm{CO}_{2}, \mathrm{CH}_{4}, \mathrm{H}_{2}$ and $\mathrm{N}_{2}$. The mixed feed was then introduced into a pre-heater that operated at $900{ }^{\circ} \mathrm{C}$. A 0.25 inch stainless steel Tee between the pre-heater and the reactor furnace allowed for various hydrocarbons, ammonia, and $\mathrm{H}_{2} \mathrm{~S}$ to be added into the synthetic biomass composition. All of these components were controlled by Sierra MFCs. The complete feed then entered the monolith reactor. The exit of the reactor fed into a condenser to knock out the water from the gaseous stream. The condenser was operated at $6{ }^{\circ} \mathrm{C}$ and the condensate accumulation was released by a level controlled solenoid valve. Removing the water from the stream enabled more accurate and consistent data to be taken using a gas chromatograph (GC). A scheme of the catalyst performance testing system is shown in Figure 10.

Figure 10. Scheme of catalyst activity testing system.

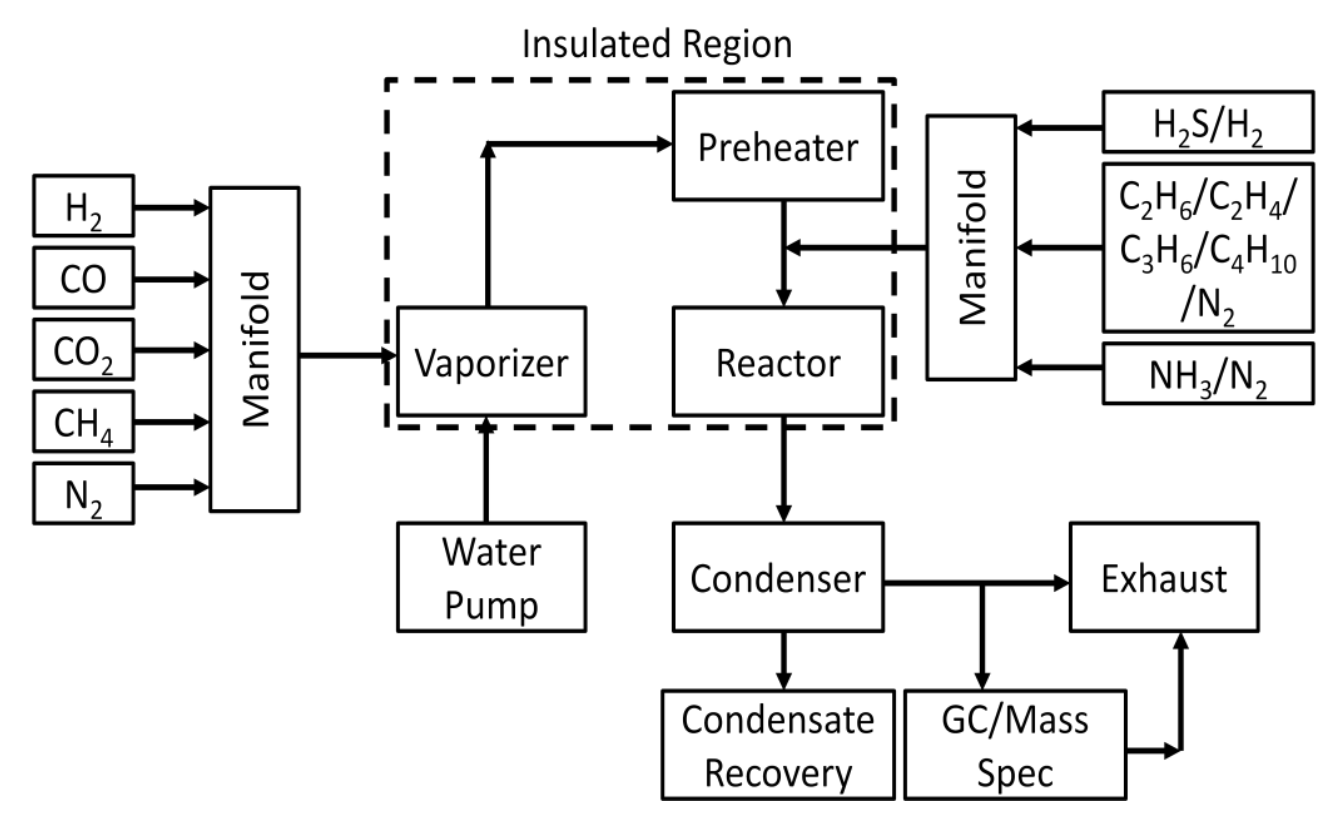

The GC for analyzing the gas compositions was an SRI 8610C Multiple Gas Analyzer No. 1. This instrument contained a 6-foot silica gel column and a 6-foot $13 \times$ molecular sieve column to separate a wide range of molecules. The GC had a thermal conductivity detector and a flame ionization detector with a methanation system. The standard setup was modified by adding copper before the methanation system to prevent $\mathrm{H}_{2} \mathrm{~S}$ from poisoning the methanation catalyst. The carrier gas was Argon at a pressure of 28 PSIG. For each injection, the column temperature was held at $30{ }^{\circ} \mathrm{C}$ for $6 \mathrm{~min}$ and then increased to $300{ }^{\circ} \mathrm{C}$ at $10{ }^{\circ} \mathrm{C} / \mathrm{min}$ heating rate. Finally the temperature was held at $300{ }^{\circ} \mathrm{C}$ for $20 \mathrm{~min}$ to bake out all gases. The GC was calibrated prior to each testing using standard mixing gases. $\mathrm{CH}_{4}$ and $\mathrm{C}_{2+}$ hydrocarbon conversions were calculated by the difference in their flow rates before the reaction and after the reaction. $\mathrm{CO}$ selectivity was determined as $[\mathrm{CO}] /\left([\mathrm{CO}]+\left[\mathrm{CO}_{2}\right]\right)$ in the product. The carbon balance in this work was $100 \pm 5 \%$. 


\section{Conclusions}

Based on the above testing data, it can be concluded that:

1. Granulated MNS catalysts achieved complete methane conversion at $900{ }^{\circ} \mathrm{C}$ and a space velocity of $24,000 \mathrm{~mL} / \mathrm{g} / \mathrm{h}$ in a simulated biomass gasification stream. Addition of $10-20 \mathrm{ppm}_{2} \mathrm{~S}$ to the stream did not significantly change the catalyst performance.

2. The MNS-extruded monolith exhibited poor activity in biomass reforming, which was attributed to a significant decrease in surface area during the monolith manufacturing process.

3. The MNS catalyst washcoated on MNS-extruded monolith achieved $90-100 \% \mathrm{CH}_{4}$ conversion at $850-900{ }^{\circ} \mathrm{C}$ and a space velocity of $10,000 \mathrm{~h}^{-1}$ in a simulated biomass gasification stream without $\mathrm{H}_{2} \mathrm{~S}$.

4. On a MNS-washcoated cordierite monolith, the addition of $22 \mathrm{ppm}_{2} \mathrm{~S}$ to a simulated biomass gasification stream decreased the initial activity at $900{ }^{\circ} \mathrm{C}$, but the activity was constant for $1200 \mathrm{~h}$ in the presence of $\mathrm{H}_{2} \mathrm{~S}$.

5. On the MNS washcoated monolith, the reforming activity decreased in a sequence of $\mathrm{C}_{3}$ hydrocarbons $>\mathrm{C}_{2}$ hydrocarbons $>$ methane.

6. On the MNS-washcoated monolith, complete $\mathrm{C}_{2+}$ hydrocarbon conversion could be achieved at $900{ }^{\circ} \mathrm{C}$ and a GHSV of $5000 \mathrm{~h}^{-1}$ in the presence of $\mathrm{H}_{2} \mathrm{~S}$.

7. The addition of $1000 \mathrm{ppm} \mathrm{NH}_{3}$ did not impact the catalytic performance at $900{ }^{\circ} \mathrm{C}$ in the presence and absence of $\mathrm{H}_{2} \mathrm{~S}$, indicating the MNS catalyst was immune to $\mathrm{NH}_{3}$.

\section{Acknowledgements}

This work was supported by the U.S. Department of Energy (Contract No. DE-FG36-04GO14314) and by the National Science (Contract Numbers 0740809 and IIP-0848877).

\section{References}

1. Bulushev, D.A.; Ross, J.R.H. Catalysis for conversion of biomass to fuels via pyrolysis and gasification: A review. Catal. Today 2011, 171, 1-13.

2. Anis, S.; Zainal, Z.A. Tar reduction in biomass producer gas via mechanical, catalytic and thermal methods: A review. Renew. Sustain. Energy Rev. 2011, 15, 2355-2377.

3. Corella, J.; Aznar, M.P.; Gil, J.; Caballero, M.A. Biomass gasification in fluidized bed: where to locate the dolomite to improve gasification? Energy Fuels 1999, 13, 1122-1127.

4. Perez, P.; Aznar, P.M.; Caballero, M.A.; Gil, J.; Martin, J.A.; Corella, J. Hot gas cleaning and upgrading with a calcined dolomite located downstream a biomass fluidized bed gasifier operating with steam-oxygen mixtures. Energy Fuels 1997, 11, 1194-1203.

5. Srinakruang, J.; Sato, K.; Vitidsant, T.; Fujimoto, K. A highly efficient catalyst for tar gasification with steam. Catal. Commun. 2005, 6, 437-440.

6. Wang, T.; Chang, J.; Lv, P. Novel catalyst for cracking of biomass tar. Energy Fuels 2005, 19, 22-27.

7. Wang, T.J.; Chang, J.C.; Wu, C.Z.; Fu, Y.; Chen, Y. The steam reforming of naphthalene over a nickel-dolomite cracking catalyst. Biomass Bioenergy 2005, 28, 508-514. 
8. Devi, L.K.; Ptasinski, J.; Janssen, F.J.J.G. Decomposition of naphthalene as a biomass tar over pretreated olivine: effect of gas composition, kinetic approach, and reaction scheme. Ind. Eng. Chem. Res. 2005, 44, 9096-9104.

9. Devi, L.; Craje, M.; Thune, P.; Ptasinski, K.J.; Janssen, F.J.J.G. Olivine as tar removal catalyst for biomass gasifiers: Catalyst characterization. Appl. Catal. A 2005, 294, 68-79.

10. Rapagnà, S.; Jand, N.; Kiennemann, A.; Foscolo, P.U. Steam-gasification of biomass in a fluidised-bed of olivine particles. Biomass Bioenergy 2000, 19, 187-197.

11. Courson, C.; Makaga, E.; Petit, C.; Kiennemann, A. Development of Ni catalysts for gas production from biomass gasification. Reactivity in steam- and dry-reforming. Catal. Today 2000, 63, 427-437.

12. Courson, C.; Udron, L.; Świerczyński, D.; Petit, C.; Kiennemann, A. Hydrogen production from biomass gasification on nickel catalysts. Catal. Today 2002, 76, 75-86.

13. Swierczynski, D.; Libs, S.; Courson, C.; Kiennermann, A. Steam reforming of tar from a biomass gasification process over Ni/olivine catalyst using toluene as a model compound. Appl. Catal. B 2007, 74, 211-222.

14. Kuhn, J.N.; Zhao, Z.; Felix, L.G.; Slimane, R.B.; Choi, C.W.; Ozkan, U.S. Olivine catalysts for methane- and tar-steam reforming. Appl. Catal. B 2008, 81, 14-26.

15. Zhang, R.; Wang, Y.; Brown, R.C. Steam reforming of tar compounds over Ni/olivine catalysts doped with $\mathrm{CeO}_{2}$. Energy Convers. Manag. 2007, 48, 68-77.

16. Li, D.; Wang, L.; Koike, M.; Nakagawa, Y.; Tomishige, K. Steam reforming of tar from pyrolysis of biomass over $\mathrm{Ni} / \mathrm{Mg} / \mathrm{Al}$ catalysts prepared from hydrotalcite-like precursors. Appl. Catal. B 2011, 102, 528-538.

17. Wang, L.; Li, D.; Koike, M.; Nakagawa, Y.; Xu, Y.; Tomishige, K. Catalytic performance and characterization of Ni-Fe catalysts for the steam reforming of tar from biomass pyrolysis to synthesis gas. Appl. Catal. A 2011, 392, 248-255.

18. Min, Z.; Asadullah, M.; Yimsiri, P.; Zhang, S.; Wu, H.; Li, C. Catalytic reforming of tar during gasification. Part I. Steam reforming of biomass tar using ilmenite as a catalyst. Fuel 2011, 90, 1847-1854.

19. Lamacz, A.; Krzton, A.; Djega-Mariadassou, G. Steam reforming of model gasification tars compounds on nickel based ceria-zirconia catalysts. Catal. Today 2011, 176, 347-351.

20. Tomishige, K.; Miyazawa, T.; Asadullah, M.; Ito, S.; Kunimori, K. Catalyst performance in reforming of tar derived from biomass over noble metal catalysts. Green Chem. 2003, 5, 399-403.

21. Schmidt, S.; Giesa, S.; Drochner, A.; Vogel, H. Catalytic tar removal from bio syngas-Catalyst development and kinetic studies. Catal. Today 2011, 175, 442-449.

22. Mendiara, T.; Johansen, J.M.; Utrilla, R.; Jensen, A.D.; Glarborg, P. Evaluation of different oxygen carriers for biomass tar reforming (II): Carbon deposition in experiments with methane and other gases. Fuel 2011, 90, 1370-1382.

23. Kong, M.; Fei, J.; Wang, S.; Lu, W.; Zheng, X. Influence of supports on catalytic behavior of nickel catalysts in carbon dioxide reforming of toluene as a model compound of tar from biomass gasification. Bioresour. Technol. 2011, 102, 2004-2008. 
24. Park, H.J.; Park, S.H.; Sohn, J.M.; Park., J.H.; Jeone, J.K.; Kim, S.S.; Park, Y.K. Steam reforming of biomass gasification tar using benzene as a model compound over various Ni supported metal oxide catalysts. Bioresour. Technol. 2010, 101, S101-S103.

25. Sato, K.; Fujimoto, K. Development of new nickel based catalyst for tar reforming with superior resistance to sulfur poisoning and coking in biomass gasification. Catal. Commun. 2007, 8, 1697-1701.

26. Yang, X.Q.; Xu, X.P.; Xu, X.L.; Liu, X.D.; Liu, C.H. Nickel supported on modified olivine catalysts for steam reforming of biomass gasification tar. Catal. Commun. 2010, 11, 383-386.

27. Caballero, M.A.; Corella, J.; Aznar, M.P.; Jil, J. Biomass gasification with air in fluidized bed-hot gas cleanup with selected commercial and full-size nickel-based catalysts. Ind. Eng. Chem. Res. 2000, 39, 1143-1154.

28. Caballero, M.A.; Aznar, M.P.; Jil, J.; Martin, J.A.; Frances, E.; Corella, J. Commercial steam reforming catalysts to improve biomass gasification with steam-oxygen mixtures. 1. Hot gas upgrading by the catalytic reactor. Ind. Eng. Chem. Res. 1997, 36, 5227-5239.

29. Pfeifer, C.; Hofbauer, H. Development of catalytic tar decomposition downstream from a dual fluidized bed biomass steam gasifier. Powder Technol. 2008, 180, 9-16.

30. Srinakruang, J.; Sato, K.; Vitidsant, T.; Fujimoto, K. Highly efficient sulfur and coking resistance catalysts for tar gasification with steam. Fuel 2006, 85, 2419-2426.

31. Miyazawa, T.; Kimura, T.; Nishikawa, J.; Kado, S.; Kunimori, K.; Tomishige, K. Catalytic performance of supported $\mathrm{Ni}$ catalysts in partial oxidation and steam reforming of tar derived from the pyrolysis of wood biomass. Catal. Today 2006, 115, 254-262.

32. Li, C.; Hirabayashi, D.; Suzuki, K. A crucial role of $\mathrm{O}_{2}{ }^{-}$and $\mathrm{O}_{2}{ }^{2-}$ on mayenite structure for biomass tar steam reforming over $\mathrm{Ni} / \mathrm{Ca}_{12} \mathrm{Al}_{14} \mathrm{O}_{33}$. Appl. Catal. B 2009, 88, 351-360.

33. Xu, C.; Donald, J.; Byambajav, E.; Ohtsuka, Y. Recent advances in catalysts for hot-gas removal of tar and $\mathrm{NH}_{3}$ from biomass gasification. Fuel 2010, 89, 1784-1795.

34. Kimura, T.; Miyazawa, T.; Nishikawa, J.; Kado, S.; Okumura, K.; Miyao, T. Development of Ni catalysts for tar removal by steam gasification of biomass. Appl. Catal. B 2006, 68, 160-170.

35. Sutton, D.; Kelleher, B.; Doyle, A.; Ross, J.R.H. Investigation of nickel supported catalysts for the upgrading of brown peat derived gasification products. Bioresour. Technol. 2001, 80, 111-116.

36. Furusawa, T.; Tsutsumi, A. Comparison of $\mathrm{Co} / \mathrm{MgO}$ and $\mathrm{Ni} / \mathrm{MgO}$ catalysts for the steam reforming of naphthalene as a model compound of tar derived from biomass gasification. Appl. Catal. A 2005, 278, 207-212.

37. Engelen, K.; Zhang, Y.; Draelants, D.J.; Baron, G.V. A novel catalytic filter for tar removal from biomass gasification gas: Improvement of the catalytic activity in presence of $\mathrm{H}_{2} \mathrm{~S}$. Chem. Eng. Sci. 2003, 58, 665-670.

38. Burattin, $\mathrm{P}$.; Che, M.; Louis, $\mathrm{C}$. Ni/SiO 2 materials prepared by deposition-precipitation: influence of the reduction conditions and mechanism of formation of metal particles. J. Phys. Chem. B 2000, 104, 10482-10489.

39. Tobiasen, L.; Sarbæk, L. Advanced Gasification in a Low Temperature Circulating Fluidised Bed Gasifier, February 2002. The European Foundation for Power Engineering (EFPE) Website. Avaibalble online: http://www.efpe.org/theses/Tobiasen_Sarbaek.pdf (accessed on 28 February 2001). 
40. Yung, M.M.; Magrini-Bair, K.A.; Parent, Y.O.; Carpenter, D.L.; Feik, C.J.; Gaston, K.R.; Pomeroy, M.D.; Phillips, S.D. Demonstration and characterization of Ni/Mg/K/AD90 used for pilot-scale conditioning of biomass-derived syngas. Catal. Lett. 2010, 134, 242-249.

41. Hepole, J.; Simell, P. Sulphur poisoning of nickel-based hot gas cleaning catalysts in synthetic gasification gas. II. Chemisorption of hydrogen sulphide. Appl. Catal. B 1997, 14, 305-321.

(C) 2012 by the authors; licensee MDPI, Basel, Switzerland. This article is an open access article distributed under the terms and conditions of the Creative Commons Attribution license (http://creativecommons.org/licenses/by/3.0/). 